\title{
Variability in the fecal egg count and the parasitic burden of hair sheep after grazing in nematode infected paddocks ${ }^{1}$
}

\author{
Roberto González-Garduño²*, Pedro Mendoza-de Gives ${ }^{3}$ and Glafiro Torres-Hernández ${ }^{4}$
}

\begin{abstract}
González-Garduño R., Mendoza-de Gives P. \& Torres-Hernández G. 2013. Variability in the fecal egg count and the parasitic burden of hair sheep after grazing in nematode infected paddocks. Pesquisa Veterinária Brasileira 33(4):469-475. Universidad Autónoma Chapingo, Unidad Regional Universitaria Sursureste, P.O. Box 29 Teapa, 86800 Tabasco, México. E-mail address: robgardu@hotmail.com

This study aimed to evaluate the variability in the fecal egg count (FEC) and the parasitic burden of naive hair sheep after grazing in nematode infected paddocks. The research was carried out in Tabasco, Mexico, during two periods (August and December). In each period 32 lambs were grazed for one month on African star grass (Cynodon plectostachyus) contaminated with gastrointestinal parasitic nematodes. FEC, packed cell volume (PCV) and body weight (BW) were recorded. Gastrointestinal worms were recovered at necropsy. Data were analyzed with the MIXED procedure of SAS using a model of repeated measurements over time. A higher number of Haemonchus contortus worms was found in December (2814 \pm 838$)$ than in August (1166 \pm 305$)$. The opposite occurred with Cooperia curticei $(2167 \pm 393$ and $3638 \pm 441$, respectively). The FEC and correlation coefficient in respect to the worm burden were higher in December (6516 $\pm 1599, \mathrm{r}=0.83$, respectively) than in August (4364 $\pm 771, \mathrm{r}=0.44$, respectively). A high variability in resistance-susceptibility to gastrointestinal nematodes (GIN) occurred in Katahdin $\times$ Pelibuey lambs after grazing.
\end{abstract}

INDEX TERMS: Haemonchus contortus, Cooperia curticei, Oesophagostomum columbianum, hair sheep, resistance-susceptibility.

\section{INTRODUCTION}

The frequent and continuous use of chemical anthelmintic drugs for deworming sheep flocks has resulted in the presence of lateral and multiple anthelmintic resistance in the parasites. This resistance leads to a concerning ineffectiveness of anthelmintics with large economic losses in sheep productivity (Coles et al. 2006, Papadopoulos 2008, Sargison 2011). Twenty-four countries have reported the presence of nematodes resistant to several anthelmintics (Jabbar et al. 2006). This situation has motivated workers around the world to search for alternative strategies to

\footnotetext{
${ }^{1}$ Received on August 3, 2012.

Accepted for publication on March 18, 2013.

${ }^{2}$ Universidad Autónoma Chapingo, Unidad Regional Universitaria Sursureste, P.O. Box 29 Teapa, 86800 Tabasco, México. *Corresponding author. robgardu@hotmail.com

${ }^{3}$ Centro Nacional de Investigación Disciplinaria en Parasitología Veterinaria, Instituto Nacional de Investigaciones Forestales, Agrícolas y Pecuarias, Paseo Cuaunahuac 8534, Progreso, C.P. 62550. Jiutepec, Morelos, México.

${ }^{4}$ Colegio de Postgraduados, Programa de Ganadería, Instituto de Recursos Genéticos y Productividad, 56230 Montecillo, Estado de México. México.
}

control these parasites (Torres-Acosta et al. 2012). Some strategies to reduce the parasitic burden in the animals have been proposed: selective deworming (Besier et al. 2010), vaccination (Arunkumar et al. 2012), medicinal plants (Sawleha et al. 2010), cooper oxide needles (Vatta et al. 2009) and biological control (Waller 2006).

Selection of sheep that are genetically resistant to gastrointestinal parasitic nematodes is another possible strategy that has been explored in recent decades (Eady et al. 2003, Hutchings et al. 2007, Stear et al. 2007). This alternative has been used in combination with other control methods, especially when there is the problem of anthelmintic drug resistance (Molento 2009). The issue of resistance has increased mainly for sheep farming in humid, warm climate conditions such as in Brazil (Thomaz-Soccol et al. 2004). In these warm, humid areas the proliferation of nematode larvae in the grass increases, resulting in the possibility of larvae completing their biological cycles, thereby creating a major problem in the grazing sheep industry (Torres-Acosta \& Hoste 2008).

The genetic selection of sheep resistant to nematodes is based on phenotypic markers. For example, the elimi- 
nation of eggs per $\mathrm{g}$ of feces in wool sheep breeds has been investigated for many years in Australia and New Zealand (Windon 1996, Gray 1997). In Merino, there are lines of sheep selected for both increased and reduced genetic resistance (Woolaston et al. 1990). These lines achieve average counts of 2730 and $17400 \mathrm{epg}$, respectively, making it possible to reduce the use of anthelmintics in controlling nematodes in sheep with genetic resistance. The search for genes or Quantitative Trait Loci (QTL) related to resistance against parasites in sheep is considered a major aspect to be investigated (Beraldi et al. 2007) by workers in some countries, i.e. UK (Davies et al. 2006, Bishop \& Morris 2007) and Kenya (Silva et al. 2012). Despite the development of modern molecular techniques, traditional productive aspects such as weight gain, packed cell volume (Vanimisetti et al. 2004) and egg faecal count have been used to diagnosis parasites (Cringoli et al. 2010).

Studies indicate that hair breeds are more resistant to parasitic nematodes than wool breeds. For instance, in a work published by Notter et al. (2003), authors recorded 4011 FEC average after four to eight weeks in wool lambs. Meanwhile, in hair lambs maintained under the same conditions, only 1135 FEC was found. On the other hand, Katahdin and St Croix have been identified as resistant to gastrointestinal parasitic nematodes with values of 5170 and 4217 FEC and Dorper lambs with 8602 FEC (Burke \& Miller 2004). Also, one hair sheep breed from the Canary Islands (Canaria hair breed sheep) (González et al. 2008) and another from Mexico (Pelibuey) are also recorded as resistant against gastrointestinal nematodes (Morteo-Gómez et al. 2004). Other studies also indicated the presence of resistance in the following breeds: Florida (Amarante et al. 1999, Díaz et al. 2000), Gulf Coast native (Li et al. 2001), Blackbelly (Amount et al. 2003), Red Maasai (Baker et al. 2003) and Dorper (Vannimiseti et al. 2004).

The high variability observed between and within breeds allows for selection based on the nematode egg count despite the heritability and repeatability being close to 0.3 (Jackson 2002). Nevertheless, it should be considered as an alternative for controlling parasitic nematodes. The aim of the present study was to identify the variability between the fecal egg count and the parasitic burden of hair sheep after grazing in nematode infected grazing paddocks.

\section{MATERIALS AND METHODS}

\section{Experimental site}

This study was carried out in the Unidad Regional Universitaria Sursureste of the Universidad Autónoma Chapingo in the Municipality of Teapa, Tabasco, Mexico, at 60 meters above sea level and located $17^{\circ} 31^{\prime} 38^{\prime \prime}$ North latitude and $92^{\circ} 55^{\prime} 50^{\prime \prime}$ West longitude. The prevalent climate of this region is Af (m) wi'g, hot and humid with rainfall throughout the year (Fig.1). The average annual temperature is $25.8^{\circ} \mathrm{C}$ and rainfall of $3976 \mathrm{~mm}$ (CONAGUA, 2012).

\section{Animals and management}

The grassland was planted with African star grass (Cynodon plectostachyus) nine months before starting the experiment. Three months before the lambs began the grazing period, one group of 40 sheep was grazed on this prairie in order to contaminate it with GIN.

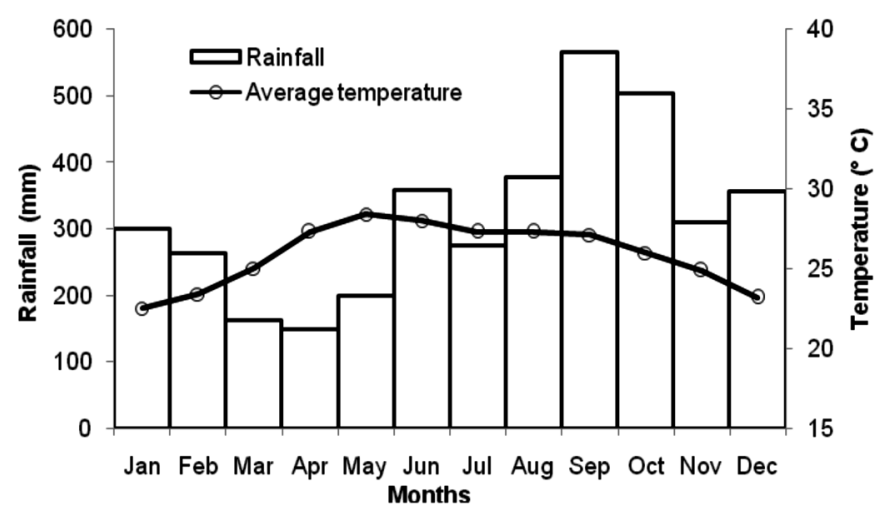

Fig.1. Rainfall and temperature averages from 1971 to 2000 recorded at the Meteorological Center, 27068 Puyacatengo, Tabasco, Mexico.

The study was divided into two periods. In each period, 32 Katahdin $\times$ Pelibuey three- month-old weaned male lambs were used. The lambs of each period had never been in contact with GIN because they were reared in house with ewes during the preweaning period. At weaning, they were negative to gastrointestinal nematodes; consequently, no acquired resistance against nematodes would be expected.

The first period was carried out in August (rainy season) and lambs were grazed for one month in a rotational system with 15 days grazing in each one of two $7500 \mathrm{~m}^{2}$ paddocks. During grazing, lambs were given $250 \mathrm{~g}$ of a commercial feed with $14 \%$ crude protein. Also, they were provided with a mineral mixture and water ad libitum. After grazing, lambs were housed for 21 days to allow the larvae to evolve into adult worms. Lambs from this group were slaughtered to recover the nematode parasites.

After completing the first grazing period, an "extra" group of 38 infected sheep were grazed on the pastures for three months from September to November (rainy season) to continuously infect the prairie with gastrointestinal nematodes.

In the second period, another group of 32 grazing lambs with the same characteristics, origin and management, previously indicated, was introduced. This group grazed for a month (December) and was then housed for 21 days. The January group was slaughtered to recover the nematode parasites.

Individual body weight (BW) was recorded at the beginning and at days 35 and 42 of each period, and the average daily weight gain (DWG) was estimated. On the same dates, blood samples were taken from the jugular vein to measure the packed cell volume (PCV) by the micro-haematocrit technique (Benjamin 1991).

\section{Parasitological method}

During grazing, fecal samples were taken on days 14, 21, 35 and 42 . During the housing period, samples were taken on days 21, 35 and 42. The McMaster technique was used to determine the FEC values (Thienpont et al. 1986). Fecal samples were pooled and then cultured to obtain nematode infective larvae for taxonomic identification (Niec 1968).

At the end of the housing time in each period, lambs were slaughtered according to the Mexican Official Standard NOM-033Z00-1995 for humanitarian slaughter of domestic animals and wildlife (SENASICA, 1996). After slaughter, the abomasum of each lamb was removed and dissected as follows: The organ was opened along the greater curvature and the content was collected in a plastic container and then the worms were recovered. At the same time, worms were recovered from the intestinal tract and also from distal part of the colon and rectum. At the same sampling time, $10 \%$ formalin was added to preserve the recovered parasi- 
tes. The content of the abomasum, colon and rectum was washed with tap water and passed through a mesh (Mesh number 50, $0.297 \mathrm{~mm}$, Mont-steel) and content of small intestine was washed and meshed through a mesh number $400(0.038 \mathrm{~mm}$, Mont-steel). Finally, the content and parasites retained in the mesh were collected in a $500 \mathrm{~mL}$ flask (Tarazona 1973). Recovered nematodes, including males and females from aliquots, were mounted on slides and observed under a microscope (10X and 40X) for the taxonomic identification (Vázquez 1989, Jacquiet et al. 1997).

\section{Statistical analysis}

Least square means and standard errors were estimated from repeated measure analysis of variance (SAS 1999). FEC was transformed to $\log _{10}(\mathrm{FEC}+25)$ to correct the heterogeneity of variance and to obtain a normal distribution approximation of data following the method of Gauly \& Erhardt (2001).

The following model was used:

$Y_{\mathrm{ijk}}=\mu+\rho_{\mathrm{i}}+\alpha_{\mathrm{j}(\mathrm{i})}+\tau_{\mathrm{k}(\mathrm{i})}+\varepsilon_{\mathrm{ijk}}$

Where: $Y_{\mathrm{ijk}}$ is the FEC, PCV or DWG, $\mu$ the mean, $\rho_{i}$ the fixed effect of period, $\alpha_{\mathrm{j}(\mathrm{i})}$ the random effect of j-esim animal in the i-esim period $\alpha_{\mathrm{j}(\mathrm{i})} \sim \mathrm{N}$ $\left(0, \sigma^{2}\right) \cdot \tau_{\mathrm{k}(\mathrm{i})}$ Fixed effect of the time, $\varepsilon_{\mathrm{ijk}} \sim \mathrm{N}\left(0, \sigma^{2}\right)$ the residual error.

The results of counting the recovered worm species (Haemonchus contortus, Cooperia curticei and Oesophagostomum colombianum) and the total worm burdens were log + 25 transformed and analyzed using the same model, but removing the effect of time. One frequency table was performed to determine the dispersion of nematode counts in the group of lambs in each period, taking as class interval 1500 nematodes with the purpose of forming more than 6 classes. The correlation analyzes were performed using the CORR procedure among the study variables with SAS software (SAS 1999) and scatter plots and trend lines in Excel.

\section{RESULTS}

The total count of recovered parasites at necropsy was $4908 \pm 4405$ for all experiment. This count included a mixture of species conformed by Haemonchus contortus, Cooperia curticei and Oesophagostomum columbianum initially identified in the coprocultures and determined by morphologic measurements of nematode males (Table 1).

Only one lamb in each of the two periods had a very low worm burden (20 in the first period and 30 in the second). Apart from these animals, $10 \%$ of the lambs in the first period and $30 \%$ in the second period had the lowest parasite burden (1500 worms). On the other hand, $3 \%$ of the animals had more than 7500 worms in the first period while about $20 \%$ in the second period exceeded this number of nematodes (Table 2).

Table 1. Morphometry of the adult male nematode species found in the gastrointestinal tract of sheep

\begin{tabular}{lccccc}
\hline \multicolumn{1}{c}{ Specie } & Location & $\mathrm{N}^{\mathrm{a}}$ Body length & \multicolumn{2}{c}{ Spicules $(\mu \mathrm{m})$} \\
\cline { 4 - 6 } & & & $(\mathrm{mm})$ & Right & Left \\
\hline H. contortus & Abomasum & 48 & $13.36 \pm 1.7$ & $39.8 \pm 2.7^{\mathrm{b}}$ & $21.0 \pm 1.7^{\mathrm{b}}$ \\
O. columbianum & Intestine & 10 & 13.5 & $800 \pm 25.0$ & $800 \pm 25.0$ \\
C. curticei & Small intestine & 20 & $c$ & $153.0 \pm 13.0$ & $153.0 \pm 13.0$
\end{tabular}

$\overline{\mathrm{a}} \mathrm{N}=$ Number of nematodes. ${ }^{\mathrm{b}}$ Measures of the hooks; the spicules measures were $407.6 \pm 15.3$.

c There was no measurement of the body because they were fixed in formalin and rolled.

\section{Table 2. Relative frequency of worm burdens in the gastrointestinal tract of sheep grazing during two study periods}

\begin{tabular}{ccccc}
\hline \multicolumn{2}{c}{ Classes } & Classes mean & \multicolumn{2}{c}{ Accumulate relative frequency (\%) } \\
\cline { 1 - 1 } $\begin{array}{c}\text { Lower } \\
\text { limit }\end{array}$ & $\begin{array}{c}\text { Upper } \\
\text { limit }\end{array}$ & value & $\begin{array}{c}\text { First period } \\
\text { (September) }\end{array}$ & $\begin{array}{c}\text { Second period } \\
\text { (January) }\end{array}$ \\
\hline 30 & 1515 & 772 & 9.7 & 31.0 \\
1515 & 3000 & 2257 & 35.5 & 55.2 \\
3000 & 4485 & 3742 & 45.2 & 65.5 \\
4485 & 5969 & 5227 & 58.1 & 72.4 \\
5969 & 7454 & 6712 & 80.6 & 75.9 \\
7454 & 8939 & 8197 & 96.8 & 79.3 \\
8939 & 10424 & 9682 & 100.0 & 86.2 \\
$10424^{\text {a }}$ & 16364 & 13394 & & 89.7 \\
16364 & 17848 & 17106 & & 93.1 \\
17848 & 19333 & 18591 & & 100.0
\end{tabular}

a Four classes were grouped.

Similar averages in the worm burdens in both periods (4989 y 4832 worms, respectively) were observed. However, there were differences in the count of each species per period. There were more H. contortus in January (2814 \pm 838$)$ than in September (1166 \pm 305$)$. The opposite situation occurred with C. curticei (Table 3); the lambs slaughtered in September had 3638 \pm 441 nematodes of this species $(\mathrm{p} \leq 0.05)$ which was a higher number than the count worms found in lambs slaughtered in January (2167 \pm 393$)$. In the case of 0 . columbianum, the lambs slaughtered in September had more worms (68 \pm 25 ) of this species compared to those recovered from the lambs sacrificed in January $(9 \pm 4)$.

There were differences in fecal egg counts between periods $(\mathrm{P} \leq 0.01)$. Higher FEC values were found in the last period (December, 6516 $\pm 1599 \mathrm{EPG}$ ) compared with the first (August, 4364 \pm 771 ). The highest FEC values were recorded at day 21 during the second period (Fig.2).

The correlation coefficient between the worm burdens and fecal egg counts in the first period ( $r=0.44)$ was lower than in the second period ( $\mathrm{r}=0.83)$. This coincided with the highest number of $H$. contortus found during the last period

Table 3. Average and standard error of worm burdens in Katahdin x Pelibuey sheep during two periods

\begin{tabular}{|c|c|c|c|c|c|c|}
\hline \multirow[t]{2}{*}{ Species and sex } & \multirow[b]{2}{*}{$\mathrm{N}^{*}$} & \multicolumn{2}{|c|}{$\begin{array}{l}\text { First period } \\
\text { (September) } \\
\text { Worm count }\end{array}$} & \multirow[b]{2}{*}{$\mathrm{N}^{*}$} & \multicolumn{2}{|c|}{$\begin{array}{c}\text { Second period } \\
\text { (January) } \\
\text { Worm count }\end{array}$} \\
\hline & & Average & Std Error & & Average & Std Error \\
\hline \multicolumn{7}{|c|}{ Haemonchus contortus } \\
\hline Females & 30 & $673^{\mathrm{b}}$ & 185 & 29 & $15299^{a}$ & 446 \\
\hline Males & 30 & $494^{\mathrm{b}}$ & 127 & 29 & $1285^{a}$ & 395 \\
\hline Total & 30 & $1166^{\mathrm{b}}$ & 305 & 29 & $2814^{\underline{a}}$ & 838 \\
\hline \multicolumn{7}{|l|}{ Cooperia curticei } \\
\hline Females & 30 & $1994^{a}$ & 219 & 29 & $1171^{\mathrm{b}}$ & 207 \\
\hline Males & 30 & $1643^{\mathbf{a}}$ & 233 & 29 & $996^{\mathrm{b}}$ & 187 \\
\hline Total & 30 & $3638^{\underline{a}}$ & 441 & 29 & $2167^{\mathrm{b}}$ & 393 \\
\hline \multicolumn{7}{|c|}{ Oesophagostomum columbianum } \\
\hline Females & 30 & $38^{\mathrm{a}}$ & 14 & 29 & $3^{\mathrm{b}}$ & 1 \\
\hline Males & 30 & 30 a & 11 & 29 & $6^{\mathrm{b}}$ & 3 \\
\hline Total & 30 & $68^{\underline{a}}$ & 25 & 29 & $9^{b}$ & 4 \\
\hline Total & 30 & $4832^{\mathrm{a}}$ & 492 & 29 & $4989^{a}$ & 1053 \\
\hline
\end{tabular}

$\overline{\text { ab }}$ Different letters in each row indicate statistical differences $(p \leq 0.01)$. $* \mathrm{~N}=$ Number of sheep. 


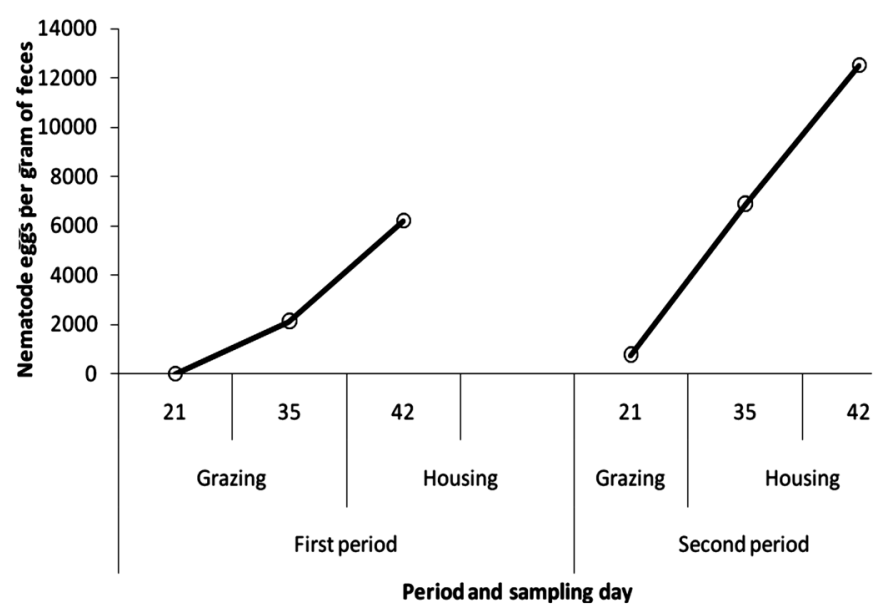

Fig.2. Fecal egg counts of gastrointestinal nematodes per period and sampling date in Kathadin x Pelibuey lambs.

and whose correlation coefficient was high $(\mathrm{r}=0.91)$ between the worm count of this species and fecal egg counts (Table 4). The fecal egg count and the worm burdens had a greater tendency after 42 days of infection (Table 5).

The PCV of lambs in the two periods decreased as the lambs became infected and the fall was more pronounced in the second period (December, Table 6). The largest reduction in PCV in the second period also coincided with the highest number of $H$. contortus and with high FEC. Therefore, the correlation coefficients between the PCV and the worm burden were negative in both periods (Table 7).

The high worm burdens coincided with the decrease in PCV values and showed a linear trend which had the best fit $\left(\mathrm{R}^{2=60 \%)}\right.$ during the second period when there was a larger number of $H$. contortus. In the first period, PCV reduction

Table 4. Correlation coefficients of fecal egg counts and worm burdens of Haemonchus contortus and Cooperia curticei in the first period (above the diagonal) and second period (below the diagonal)

\begin{tabular}{|c|c|c|c|c|c|}
\hline & Variable & $\begin{array}{l}\text { Worm } \\
\text { count }\end{array}$ & FEC & $\begin{array}{l}\text { H. contortus } \\
\text { worms }\end{array}$ & $\begin{array}{c}\text { C. curticei } \\
\text { worms }\end{array}$ \\
\hline \multirow{5}{*}{ 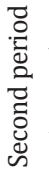 } & & \multicolumn{4}{|c|}{ First period } \\
\hline & Worm count & 1 & $0.44^{*}$ & $0.44^{*}$ & $0.80^{* *}$ \\
\hline & FEC $^{\mathrm{a}}$ & $0.83^{* *}$ & 1 & $0.86^{* *}$ & $-0.09^{\text {ns }}$ \\
\hline & H. contortus worms & $0.94^{* *}$ & $0.91^{* *}$ & 1 & $-0.18^{\text {ns }}$ \\
\hline & C. curticei worms & $0.68^{* *}$ & $0.29^{\mathrm{ns}}$ & $0.38^{*}$ & 1 \\
\hline
\end{tabular}

Table 5. Trend among fecal counts of nematode eggs ( $x$ ) and the number of worms $(\mathrm{Y})$ found in the gastrointestinal tract in mixed infections of Haemonchus contortus and Cooperia curticei

\begin{tabular}{|c|c|c|c|c|}
\hline \multirow{2}{*}{$\begin{array}{c}\text { Days after } \\
\text { infection }\end{array}$} & \multicolumn{2}{|l|}{ Worm count } & \multicolumn{2}{|l|}{ Female worm count } \\
\hline & equation & $\mathrm{R}^{2}$ & equation & $\mathrm{R}^{2}$ \\
\hline \multicolumn{5}{|c|}{ First period ${ }^{a}$} \\
\hline 35 & $Y=1509 x^{0.153}$ & 0.16 & $Y=868 x^{0.15}$ & 0.16 \\
\hline 42 & $Y=264.6 x^{0.339}$ & 0.47 & $\mathrm{Y}=161.7 \mathrm{x}^{0.329}$ & 0.45 \\
\hline \multicolumn{5}{|c|}{ Second period } \\
\hline 21 & $\mathrm{Y}=199.3 \mathrm{x}^{0.437}$ & 0.44 & $\mathrm{Y}=120.7 \mathrm{x}^{0.422}$ & 0.42 \\
\hline 35 & $Y=-5^{*} 10^{-6} x^{2}+0.544 x+2056$ & 0.58 & $Y=-3^{*} 10^{-6} x^{2}+0.303 x+1108$ & 0.58 \\
\hline 42 & $Y=-2^{*} 10^{-6} x^{2}+0.412 x+1659$ & 0.75 & $Y=-1^{*} 10^{-6} \mathrm{x}^{2}+0.230 \mathrm{x}+891.1$ & 0.75 \\
\hline
\end{tabular}

Table 6. Percentage of packed cell volume and body weight per period in Katahdin $x$ Pelibuey sheep

\begin{tabular}{lcccccc}
\hline Day and period & & \multicolumn{2}{c}{ Packed cell volume } & & \multicolumn{2}{c}{ Body weight } \\
\cline { 7 - 7 } \cline { 6 - 7 } & & Average & Std dev & & Average & Std dev \\
\hline First period & & & & & & \\
1 & 31 & 28.8 & 2.7 & & 19.4 & 4.0 \\
35 & 31 & 28.6 & 3.9 & & 19.0 & 4.1 \\
42 & 30 & 26.7 & 3.6 & & 20.2 & 4.2 \\
Second period & & & & & \\
1 & 32 & 33.5 & 2.3 & & 21.4 & 5.7 \\
21 & 31 & 27.7 & 3.8 & & \\
35 & 30 & 23.9 & 4.8 & & 21.1 & 5.2 \\
42 & 30 & 25.6 & 5.9 & & 22.2 & 5.5
\end{tabular}

Table 7. Correlation coefficients between the worm burden, fecal egg count (FEC), change in packed cell volume (PCV) and daily weight gain (DWG) of sheep in the first period (above the diagonal) and the second period (below the diagonal)

\begin{tabular}{|c|c|c|c|c|}
\hline Variable & Worm count & FEC & PCV change & DWG \\
\hline & \multicolumn{4}{|c|}{ First period } \\
\hline Worm count & 1 & $0.44^{*}$ & $-0.44^{*}$ & $-0.38^{*}$ \\
\hline 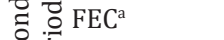 & $0.83^{* *}$ & 1 & $-0.56^{* *}$ & $-0.91^{* *}$ \\
\hline \&CV change & $-0.78^{* *}$ & $-0.77^{* *}$ & 1 & $0.55^{* *}$ \\
\hline s 2 DWG & $-0.67^{* *}$ & $-0.68^{* *}$ & $0.81^{* *}$ & 1 \\
\hline
\end{tabular}

$\bar{*} \mathrm{P} \leq 0.05 ;{ }^{* *} \mathrm{P} \leq 0.001$; ${ }^{\text {ns }} \mathrm{P} \geq 0.05$.

was lower and less adjusted to the total count of worms in the gastrointestinal tract $\left(\mathrm{R}^{2}=60 \%\right)$.

The BW of the lambs fell in the initial samples and then increased (Table 6). In DWG differences were found between the two periods $(p \leq 0.05)$. The DWG in the first period was lower than the second period and the most important changes were observed over time.

\section{DISCUSSION}

The high coefficient of variation (93\%) found in the worm burden indicates that a wide variability exists in the innate resistance-susceptibility of a contemporary group of hair sheep against gastrointestinal nematodes. The worm burdens observed in this study (30 to 19333) were similar to values found (from 7364 to about 19193) in grazing sheep (Uriarte et al. 2003). The wide variation among hosts has also been identified in Teladorsargia circumcincta parasitized sheep. This variability has also been widely recognized among and within breeds (Dominik 2005, Idris et al. 2012) and has been attributed to differences in the ingestion of infective larvae and the immune response (Stear et al. 2007).

During the first period, the correlation coefficient between FEC and worm burdens was smaller $(r=0.44)$ than the one recorded in the second period $(\mathrm{r}=0.83)$. The correlation was the result of lower FEC recorded in August (4363) due to the lowest number of adult worms of $H$. contortus (1166) and high counts of Cooperia curticei (3638). In December the highest FEC (6516) coincided with the high number of specimens of Haemonchus contortus (2814) and the smallest number of $C$. curticei (2167). In a similar case, a high correlation between worm burdens and FEC ( 0.64 to 0.73 ) in Rhön sheep infected with H. contortus was recorded (Gauly et al. 2002). Also, a high correlation (0.85 to 0.91 ) between pre-slaughter FEC and total trichostron- 
gyle burdens in Romney lambs has been identified (Bisset et al. 1996). It is noteworthy that in the case of a mixed infection (H. contortus and $C$. curticei) the correlation values were dependent on the abundance of $H$. contortus $(\mathrm{r}=0.86$ in the first period and $\mathrm{r}=0.91$ in the second period) rather than those of $C$. curticei $(\mathrm{R}=-0.09$ in the first period and $r=0.29$ in the second period; not significant).

As noted in the study of Amarante (2000), with field infections the FEC does not reflect parasitic burdens. Other factors such as the abundance of each species and the oviposition rate become important. In the case of $H$. contortus the oviposition rate is very high, ranging between 500010000 eggs per day per female worm (Coyne et al. 1991, Romero \& Boero, 2001). Whereas for the case of C. curticei, studies have reported a rate of 20 to 60 eggs and low values of correlation between the FEC and total worms (Amarante 2000).

It is also important to consider the immunological effect of lambs. In this regard, some studies have shown that lambs can not only effectively limit worm establishment, but can also suppress fecundity of those worms which do manage to establish (Bisset et al. 1996). The correlation observed between adult worm size and egg content leads to the hypothesis that egg production in $H$. contortus is limited by immune regulation of worm size and presumably growth. Mean worm size and fecundity declined as sheep received more prolonged trickle infections before necropsy, confirming that immune responses to adult worms are enhanced by ongoing larval challenge (Valderrabano et al. 2002, Rowe et al. 2008).

The relation between FEC and worm burden had a better fit after 35 days infection because the pre-patent period is about 15-28 days (Romero \& Boero 2001) and on day 21 many animals had not excreted eggs. Therefore, the FEC does not correlate well with worm count, while on days 35 and 42 the curves are fitted over $50 \%$. In the same manner as in the present study, the first egg counts did not correlate well following natural challenge in Romney lambs (Bisset et al. 1996).

A greater number of lambs with high worm burdens in the second period could be explained by the increase in infection of pastures once the number of grazing cycles had been increased. In the first period (September) lambs grazed on paddocks previously infected during three months by one flock. The lambs in the second period grazed on the same paddocks in which other flocks grazed for three more months; therefore, there were more cycles of infection in the pasture. So, more generations of parasites were contaminating such paddocks. Similar results have been recorded in Spain and they are considered as a cause of increased infection in Aragonesa sheep (Uriarte et al. 2003). However, environmental conditions could also affect the amount of parasites present in the pasture. During the months from September to December, the moisture increases in the region (Fig.1). Therefore, the environmental conditions lead to increase the nematode populations (Eysker et al. 2005).

The high frequency of $H$. contortus in the study area was reported in previous studies. This frequency was determined through fecal culture (González et al. 2003) and by using the same methodology. An abundance of $C$. curticei in this area was observed in both the rainy season and in winter (Vasquez et al. 2006). A previous study in Tabasco, Mexico, also confirms the higher prevalence of $H$. contortus in January compared with September, October and November. This study found abundance of $C$. curticei in July and August (González-Garduño et al. 2011).

In this study the negative relationship between the FEC and PCV was clear. This behavior is also reported in other breeds such as Dorset, Dorper and Kathadin by Vannimisetti et al. (2004), who found correlation coefficients of -0.46 between PCV and FEC. In other studies, PCV and FEC values were observed in Rhön sheep. A correlation range of $r=-0.21$ to -0.34 (Gauly \& Erhardt 2001, Gauly et al. 2002), which was lower than those observed in the present study, was found. This can probably be explained because these authors evaluated only the PCV values. In the present study our information included the change in PCV levels.

As expected, weight gain, worm burdens and FEC are reversed with negative correlation coefficients (Table 7). This situation has already been stated in general terms in other breeds with smaller values ( $r=-0.25$; Vanimisetti et al. 2004).

The low initial DWG was due to the drastic change of food system from confinement to grazing of all sheep. A similar situation occurred in the second period. The BW of the lambs fell in the initial samples and then increased perhaps as a result of management that was provided. For example, during the first month of grazing, lambs were supplemented with $250 \mathrm{~g}$ of commercial food and were housed with ad libitum food the following 21 days.

These results showed that Katahdin x Pelibuey sheep had a high variation in resistance-susceptibility to gastrointestinal parasitic nematodes and at least $3 \%$ of the animals showed high resistance to nematode parasitic burden.

Fecal egg count may be a suitable indicator to estimate the number of $H$. contortus since the correlation coefficients were high. However, the relationship between FEC and the total number of $C$. curticei was not a good indicator for mixed infections.

\section{REFERENCES}

Amarante A.F.T., Craig T.M., Ramsey W.S., El-Sayed N.M., Desouki A.Y. \& Bazer F.W. 1999. Comparison of naturally acquired parasite burdens among Florida Native, Rambouillet and crossbreed ewes. Vet. Parasitol. 85:61-69.

Amarante A.F.T. 2000. Relationship between faecal egg count and total worm counts in sheep infected with gastrointestinal nematodes. Braz. J. Vet. Parasitol. 9(1):45-50.

Arunkumar S., Basith A.S. \& Gomathinayagam S. 2012. A comparative analysis on serum antibody levels of sheep immunized with crude extract and thiol-purified excretory/secretory antigen of Haemonchus contortus. Vet. World. 5(5):279-284.

Aumont G., Gruner L. \& Hostache G. 2003. Comparison of the resistance to sympatric and allopatric isolates of Haemonchus contortus of Black Belly sheep in Guadeloupe (FWI) and of INRA 401 sheep in France. Vet. Parasitol. 116:139-150.

Baker R.L., Nagda S., Rodríguez-Zas S.L., Southey B.R., Audho J.O., Aduda E.O. \& Thorpe W. 2003. Resistance and resilience to gastro-intestinal nematode parasites and relationships with productivity of Red Maasai, Dorper and Red Maasai x Dorper crossbred lambs in the sub-humid tropics. Anim. Sci. 76:119-136. 
Benjamin M.M. 1991. Manual de Patología Clínica en Veterinaria. Ed. Limusa, México. 421p.

Beraldi D., McRae A.F., Gratten J., Pilkington J.G., Slate J., Visscher P.M. \& Pemberton J.M. 2007. Quantitative trait loci (QTL) mapping of resistance to strongyles and coccidia in the free-living Soay sheep (Ovis aries). Int. J. Parasitol. 37:121-129.

Besier R.B., Love R.A., Lyon J. \& Van Burgel A.J. 2010. A targeted selective treatment approach for effective and sustainable sheep worm management: investigations in Western Australia. Anim. Prod. Sci. 50:1034-1042.

Bishop S.C. \& Morris C.A. 2007. Genetics of disease resistance in sheep and goats. Small Rum. Res. 70:48-59.

Bisset S.A., Vlassoff A., Douch P.G.C., Jonas W.E., West C.J. \& Green R.S. 1996. Nematode burdens and immunological responses following natural challenge in Romney lambs selectively bred for low or high faecal worm egg count. Vet. Parasitol. 61:249-263.

Burke J.M. \& Miller J.E. 2004. Relative resistance to gastrointestinal nematode parasites in Dorper, Katahdin, and St. Croix lambs under conditions encountered in the southeastern region of the United States. Small Rum. Res. 54:43-51.

Coles G.C., Jackson F., Pomroy W.E., Prichard R.K., von Samson-Himmelstjerna G., Silvestre A., Taylor M.A. \& Vercruysse J. 2006. The detection of anthelmintic resistance in nematodes of veterinary importance. Vet. Parasitol. 136:167-185.

CONAGUA. 2012. Servicio Meteorológico Nacional. Normales climatológicas de la estación 27068 Puyacatengo <http://smn.cna.gob.mx/climatologia/normales/estacion/tab/NORMAL27068.TXT> Accesed Jan. 10, 2012.

Coyne M.J., Smith G. \& Johnstone C. 1991. A study of the mortality and fecundity of Haemonchus contortus in sheep following experimental infections. Int. J. Parasitol. 21:847-853.

Cringoli G., Rinaldi L., Maurelli M.P. \& Utzinger J. 2010. FLOTAC: new multivalent techniques for qualitative and quantitative copromicroscopic diagnosis of parasites in animals and humans. Nat. Protocols 5:503-515. doi:10.1038/nprot.2009.235.

Davies G., Stear M.J., Benothman M., Abuagob O., Kerr A., Mitchell S. \& Bishop S.C. 2006. Quantitative trait loci associated with parasitic infection in Scottish blackface sheep. Heredity 96:252-258.

Díaz R.P., Torres H.G., Osorio A.M.M., Pérez P.H., Pulido A.A.R., Becerril P.C. \& Herrera H.J.G. 2000. Resistencia genética a parásitos gastrointestinales en ovinos Florida, Pelibuey y sus cruzas en el trópico Mexicano. Agrociencia 34(1):13-20.

Dominik S. 2005. Quantitative trait loci for internal nematode resistance in sheep: a review. Gen. Sel. Evol. 37(Suppl.1):S83-S96.

Eady S.J., Woolaston R.R. \& Barger I.A. 2003. Comparison of genetic and nongenetic strategies for control of gastrointestinal nematodes of sheep. Liv. Prod. Sci. 81:11-23.

Eysker M., Bakker N., Kooyman F.N.J. \& Ploeger H.W. 2005. The possibilities and limitations of evasive grazing as a control measure for parasitic gastroenteritis in small ruminants in temperate climates. Vet. Parasitol. 129:95-104.

Gauly M. \& Erhardt G. 2001. Genetic resistance to gastrointestinal nematode parasites in Rhön sheep following natural infection. Vet. Parasitol. 102:253-259.

Gauly M., Kraus M., Vervelde L., van Leeuwen M.A.W. \& Erhardt G. 2002. Estimating genetic differences in natural resistance in Rhön and Merinoland sheep following experimental Haemonchus contortus infection. Vet. Parasitol. 106:55-67.

González G.R., Torres H.G., Nuncio O.M.G.J., Cuéllar O.J.A. \& Zermeño G.M.E. 2003. Detección de eficiencia antihelmíntica en nematodos de ovinos de pelo con la prueba de reducción de huevos en heces. Livest. Res. Rural Develop. 15(12):1-10. <http://www.lrrd.org/lrrd15/12/gonza1512. htm> Accesed Jan. 15, 2012

González J.F., Hernández A., Molina J.M., Fernández A., Raadsma H.W., Meeusen E.N.T. \& Piedrafita D. 2008. Comparative experimental Haemonchus contortus infection of two sheep breeds native to the Canary Islands. Vet. Parasitol. 153:374-378.
González-Garduño R., Torres-Hernández G., Córdova-Pérez C., Mendoza-de Gives P. \& Arece-García J. 2011. Prevalencia de parásitos gastrointestinales en ovinos sacrificados en un rastro de Tabasco, México. Vet. Méx. 42(2):125-135.

Gray G.D. 1997. The use of genetically resistant sheep to control nematode parasitism. Vet. Parasitol. 72:345-366.

Hutchings M.R., Knowler K.J., McAnulty R. \& McEwan J.C. 2007. Genetically resistant sheep avoid parasites to a greater extent than do susceptible sheep. Proc. R. Soc. B 1620:1839-1844.

Idris A., Moors E., Sohnrey B. \& Gauly M. 2012. Gastrointestinal nematode infections in German sheep. Parasitol. Res. 110:1453-1459.

Jabbar A., Iqbal Z., Kerboeuf D., Muhammad G., Khan M.N. \& Afaq M. 2006. Anthelmintic resistance: the state of play revisited. Life Sci. 79:24132431.

Jackson F. 2002. Selección genética en pequeños rumiantes, p.103-107. In: Torres A.J.F. \& Aguilar C.A.J. (Eds), 2 o Curso Internacional del Epidemiología y Control Integral de Nematodos Gastrointestinales de Importancia Económica en Pequeños Rumiantes. Fundación Produce Yucatán A.C. Mérida, Yuc.

Jacquiet P., Cabaret J., Cheikh D. \& Thiam E. 1997. Identification of Haemonchus species in domestic ruminants based on morphometrics of spicules. Parasit. Res. 83:82-86.

Li Y., Miller J.E. \& Franke D.E. 2001. Epidemiological observations and heterosis analysis of gastrointestinal nematode parasitism in Suffolk, Gulf Coast Native, and crossbred lambs Vet. Parasitol. 98:273-283.

Molento M.B. 2009. Parasite control in the age of drug resistance and changing agricultural practices. Vet. Parasitol. 163:229-234.

Morteo-Gómez R., González-Garduño R., Torres-Hernández G., Nuncio-Ochoa G., Becerril-Pérez C.M., Gallegos-Sánchez J. \& Aranda-Ibañez E. 2004. Efecto de la variación fenotípica en la resistencia de corderos Pelibuey a la infestación con nematodos gastrointestinales. Agrociencia 38(4):395-404.

Niec R. 1986. Cultivo e identificación de larvas infectantes de nematodos gastroentéricos del bovino y ovino. Manual Técnico 3. Instituto Nacional de Tecnología Agropecuaria, Buenos Aires, Argentina.

Notter D.R., Andrew S.A. \& Zajac A.M. 2003. Responses of hair and wool sheep to a single fixed dose of infective larvae of Haemonchus contortus. Small Rumin. Res. 47:221-225.

Papadopoulos E. 2008. Anthelmintic resistance in sheep nematodes. Small Rumin. Res. 76:99-103.

Romero J.R. \& Boero C.A. 2001. Epidemiología de la gastroenteritis verminosa de los ovinos en las regiones templadas y cálidas de la Argentina. Analecta Vet. 21(1):21-37.

Rowe A., McMaster K., Emery D. \& Sangster N. 2008. Haemonchus contortus infection in sheep: Parasite fecundity correlates with worm size and host lymphocyte counts. Vet. Parasitol. 153:285-293.

Sargison N. 2011. Farm animal practice: Responsible use of anthelmintics for nematode control in sheep and cattle. In Practice 33:318-327.

SAS Institute, 1999. The SAS System for Windows. Version 8. SAS Institute, Cary, N.C.

Sawleha Q., Dixit A.K. \& Dixit P. 2010. Use of medicinal plants to control Haemonchus contortus infection in small ruminants. Vet. World 3(11):515-518.

SENASICA 1996. Sacrificio humanitario de los animales domésticos y silvestres. <http://www.senasica.gob.mx/?doc=529> Accesed Jan. 20, 2012.

Silva M.V.B., Sonstegard T.S., Hanotte O., Mugambi J.M., Garcia J.F., Nagda S., Gibson J.P., Iraqi F.A., McClintock A.E., Kemp S.J., Boettcher P.J., Malek M., Van Tassell C.P. \& Baker R.L. 2012. Identification of quantitative trait loci affecting resistance to gastrointestinal parasites in a double backcross population of Red Maasai and Dorper sheep. Anim. Gen. 43:63-71.

Stear M.J., Fitton L., Innocent G.T., Murphy L., Rennie K. \& Matthews L. 2007. The dynamic influence of genetic variation on the susceptibility of sheep to gastrointestinal nematode infection. J. R. Soc. Interf. 4:767-776.

Tarazona V.J.M. 1973. Manual de Técnicas de Parasitología Veterinaria. Editorial Acribia, Zaragoza. 196p. 
Thienpont D., Rochette F. \& Vanparijs O.F.J. 1986. Diagnóstico de las Helmintiasis por Medio del Examen Coprológico. Janssen Research Foundation, Beerse, Bélgica. 205p.

Thomaz-Soccol V., Pohl de Souza F., Sotomaior C., Alcântara Castro E., Milczewski V., Mocelin G. \& Pessoa e Silva M. 2004. Resistance of gastrointestinal nematodes to anthelmintics in sheep (Ovis aries). Braz. Arch. Biol. Technol. 47(1):41-47. (Online) [Cited 2013-02-26]. Doi: 10.1590/ S1516-89132004000100006

Torres-Acosta J.F.J. \& Hoste H. 2008. Alternative or improved methods to limit gastro-intestinal parasitism in grazing sheep and goats. Small Rum. Res. 77:159-173.

Torres-Acosta J.F.J., Molento M. \& Mendoza de Gives P. 2012. Research and implementation of novel approaches for the control of nematode parasites in Latin America and the Caribbean: Is there sufficient incentive for a greater extension effort? Vet. Parasitol. 186:132-142.

Uriarte J., Llorente M.M. \& Valderrábano J. 2003. Seasonal changes of gastrointestinal nematode burden in sheep under an intensive grazing system. Vet. Parasitol. 118:79-92.

Valderrábano J., Delfa R. \& Uriarte J. 2002. Effect of level of feed intake on the development of gastrointestinal parasitism in growing lambs. Vet. Parasitol. 104:327-338.
Vanimisetti H.B., Greiner S.P., Zajac A.M. \& Notter D.R. 2004. Performance of hair sheep composite breeds: Resistance of lambs to Haemonchus contortus. J. Anim. Sci. 82:595-604.

Vásquez H.M., González G.R., Torres H.G., Mendoza de G.P. \& Ruiz R.J.M. 2006. Comparación de dos sistemas de pastoreo en la infestación con nematodos gastrointestinales en ovinos de pelo. Vet. Méx. 37:15-27.

Vatta F.A., Waller J.P., Githiori B.J. \& Medley F.G. 2009. The potential to control Haemonchus contortus in indigenous South African goats with copper oxide wire particles. Vet. Parasitol. 162(3/4):306-313.

Vázquez P.V.M. 1989. Necropsia e identificación de helmintos del tracto gastroentérico de rumiantes, p.72-82. In: Campos R. \& Bautista G. (Eds), Diagnóstico de Helmintos y Hemoparásitos de Rumiantes. Asociación Mexicana de Parasitología Veterinaria, Jiutepec, Morelos, México.

Waller P.J. 2006. Sustainable nematode parasite control strategies for ruminant livestock by grazing management and biological control. Anim. Feed Sci. Tech. 126(3/4):277-289.

Windon R.G. 1996. Genetic control of resistance to helminths in sheep. Vet. Immunol. lmmunopathol. 54:245-254.

Woolaston R.R., Barger I.A. \& Piper L.R. 1990. Response to helminth infection of sheep selected for resistance to Haemonchus contortus. Int. J. Parasitol. 20(8):1015-1018. 